\title{
STRUKTUR KEPRIBADIAN TOKOH DALAM NOVEL SURAT KECIL UNTUK TUHAN KARYA AGNES DAVONAR
}

\author{
Ihsan Abraham \\ Fakultas Bahasa dan Sastra \\ Universitas Kanjuruhan Malang \\ ihsanabraham59@gmail.com
}

\begin{abstract}
Abstrak: Penelitian ini mendeskripsikan struktur kepribadian tokoh utama Keke dan tokoh bawahan Ayah serta Andi dalam novel Surat Kecil untuk Tuhan karya Agnes Davonar. Metode yang digunakan dalam penelitian ini adalah kualitatif deskriptif, sedangkan pendekatan yang digunakan adalah pendekatan psikologi sastra, teori struktur kepribadian Sigmund Freud yang meliputi $i d$ atau das es, ego atau das ich, superego atau das ueber ich. Data penelitian ini berupa kata-kata dan tindakan serta kutipan yang berkaitan dengan struktur kepribadian tokoh utama Keke, struktur kepribadian tokoh tambahan Ayah, dan struktur kepribadian tokoh tambahan Andi. Sumber data diperoleh dari novel Surat Kecil Untuk Tuhan Karya Agnes Davonar. Instrumen utama penelitian ini adalah peneliti sendiri serta dibantu oleh kisi-kisi penjaringan data berupa tabel. Hasil yang diperoleh dari penelitian ini menunjukkan bahwa struktur kepribadian tokoh utama Keke, tokoh bawahan Ayah, dan tokoh bawahan Andi dalam novel "Surat Kecil Untuk Tuhan” karya Agnes Davonar dibagi menjadi tiga unsur, yakni id atau das es, ego atau das ich, superego atau das ueber ich.
\end{abstract}

Kata Kunci: struktur kepribadian, tokoh, novel

Abstract: This study aimed at describing the personality structure of the main character Keke and figures of Father and Andi of novel Surat Kecil untuk Tuhan, written by Agnes Davonar. The method applied in this study was descriptive qualitative while the approach was psychoanalytic literary, personality structure theory of Sigmund Freud which consisted of id or das es, ego or das ich, superego or das ueber ich. Data of this study was in form of words and actions as well as quotation related with the personality structure of Keke as the main character, the personality structure of father as cameo role and personality structure of Andi as another cameo role. Data source was achieved from the novel Surat Kecil untuk Tuhan written by Agnes Davonar. The main instruments of this study were the researchers himself and was supported by content network data in form of table. The result of the study showed that the personality structure of Keke as the main character, the Father and Andi as cameo roles in the novel of Surat Kecil untuk Tuhan written by Agnes Davonar was divided into three elements namely id or das es, ego or das ich, superego or das ueber ich.

Keywords: personality structure, character, novel

\section{PENDAHULUAN}

Novel adalah sebuah karya fiksi yang menawarkan sebuah dunia; dunia yang berisi model kehidupan yang diidealkan, yaitu dunia imajinatif yang dibangun melalui berbagai unsur intrinsiknya seperti peristiwa, plot, tokoh, latar, dan sudut pandang yang kesemuanya tentu saja juga bersifat imajinatif. Kesemuanya itu walau bersifat noneksistensial, karena dengan sengaja 
dikreasikan oleh pengarang, dibuat mirip, diimitasikan atau dianalogikan dengan dunia nyata lengkap dengan peristiwa-peristiwa dan latar aktualnya sehingga tampak seperti sungguh ada dan terjadi (Nurgiyantoro, 1995: 4).

Tokoh adalah orang-orang yang ditampilkan dalam suatu karya naratif, atau drama, yang oleh pembaca ditafsirkan memiliki kualitas moral dan kecenderungan tertentu seperti yang diekspresikan dalam ucapan dan apa yang dilakukan dalam tindakan(Nurgiyantoro, 1995: 166).

Dilihat dari segi peranan atau tingkat pentingnya tokoh dalam sebuah cerita, ada tokoh yang tergolong penting dan ditampilkan secara terus menerus, sehingga terasa mendominasi sebagian besar cerita yang biasanya disebut tokoh utama (central character, main character). Sebaliknya ada tokoh yang hanya dimunculkan sekali atau beberapa kali dalam cerita, dan itu pun mungkin dalam porsi penceritaan yang relatif pendek yang disebut tokoh tambahan (peripheral character). Tokoh utama adalah tokoh yang diutamakan penceritaannya dalam novel yang bersangkutan. Ia merupakan tokoh yang paling banyak diceritakan, baik sebagai pelaku kejadian maupun yang dikenai kejadian. Di lain pihak pemunculan tokoh tambahan dalam keseluruhan cerita lebih sedikit dan kehadirannya hanya jika ada keterkaitannya dengan tokoh utama (Nurgiyantoro, 1995: 177).

Kepribadian adalah bagian dari jiwa yang membangun keberadaan manusia menjadi satu kesatuan, tidak terpecah-belah dalam fungsifungsi. Memahami kepribadian berarti memahami aku, diri, self, atau memahami manusia seutuhnya (Alwisol, 2004: 2).

Sastra dan psikologi memang mempunyai pertautan yang erat, secara tidak langsung dan fungsional. Pertautan tidak langsung, karena baik sastra maupun psikologi memiliki objek yang sama yaitu kehidupan manusia. Psikologi dan sastra memiliki hubungan fungsional karena sama-sama untuk mempelajari keadaan jiwa orang lain, bedanya dalam psikologi gejala tersebut riil, sedangkan dalam sastra bersifat imajinatif. Sastra bisa juga dikatakan sebagai ungkapan jiwa, sastra adalah wakil jiwa lewat bahasa. Dengan demikian dapat diartikan bahwa sastra tidak mampu melepaskan diri dari aspek psikis. Psikologi sastra juga memandang bahwa sastra merupakan hasil kreativitas pengarang yang menggunakan bahasa, yang diabadikan untuk kepentingan estetis. Sastra merupakan hasil ungkapan jiwa pengarang yang di dalamnya ternuansakan suasana kejiwaan sang pengarang, baik suasana pikir maupun suasana rasa (emosi) (Endraswara, 2008: 86).

Teori psikoanalisis adalah disiplin ilmu yang dicetuskan oleh Sigmund Freud sekitar tahun 1900-an. Teori psikoanalisis berhubungan dengan fungsi dan perkembangan mental manusia merupakan bagian dari psikologi yang memberikan kontribusi besar, sehingga dijadikan sebagai dasar ilmu psikologi yang dikenal sekarang (Minderop, 2010: 11).

Teori psikologi yang paling dominan dalam analisis karya sastra adalah teori Sigmund Freud. Menurut Freud, teori kepribadian pada umumnya dibagi menjadi tiga bagian, (1) id atau das es, (2) ego atau das ich, (3) superego atau das ueber ich. Teori Freud dimanfaatkan untuk mengungkapkan berbagai gejala psikologis di balik gejala bahasa.

Id adalah sistem kepribadian yang asli, dibawa sejak lahir. Dari id akan lahir ego dan superego. Freud mengibaratkan id sebagai raja atau ratu, ego sebagai perdana menteri dan superego sebagai pendeta tertinggi. Id berlaku seperti penguasa absolut, harus dihormati, manja, sewenang-wenang dan mementingkan diri sendiri; apa yang diinginkannya harus segera terlaksana. Id merupakan energi psikis dan naluri yang menekan manusia agar memenuhi kebutuhan dasar seperti misalnya kebutuhan: makan, seks menolak rasa sakit atau tidak nyaman. Cara kerja id berhubungan dengan prinsip kesenangan, yakni selalu mencari kenikmatan dan selalu menghindari ketidaknyamanan (Minderop, 2010: 21).

Ego adalah eksekutif (pelaksana) dari 
kepribadian, yang memiliki dua tugas utama; pertama, memilih stimuli mana yang hendak direspon dan atau insting mana yang akan dipuaskan sesuai dengan prioritas kebutuhan. Kedua, menentukan kapan dan bagaimana kebutuhan itu dipuaskan sesuai dengan tersedianya peluang yang risikonya minimal. Dengan kata lain, ego sebagai eksekutif kepribadian berusaha memenuhi kebutuhan $i d$ sekaligus juga memenuhi kebutuhan moral dan kebutuhan berkembang mencapai kesempurnaan dari superego (Alwisol, 2004: 16).

Superego adalah kekuatan moral dan etik dari kepribadian, yang beroperasi memakai prinsip idealistik sebagai lawan dari kepuasan id dan prinsip realistik ego. Prinsip idealitik mempunyai dua subprinsip yakni conscience dan ego ideal. Superego pada hakekatnya merupakan elemen yang mewakili nilai-nilai orang tua atau interpretasi orang tua mengenai standar sosial yang diajarkan kepada anak melalui berbagai larangan dan perintah. Apapun tingkahlaku yang dilarang dianggap salah dan dihukum oleh orang tua akan diterima anak menjadi suara hati (conscience) yang berisi apa saja yang tidak boleh dilakukan. Apapun yang disetujui, dihadiahi dan dipuji orang tua akan diterima menjadi standar kesempurnaan atau ego ideal yang berisi apa saja yang harus dilakukan (Alwisol, 2004: 16).

Penelitian ini mengambil sumber dari karya sastra dalam bentuk novel. Adapun novel yang dipilih adalah novel Surat Kecil Untuk Tuhan karya Agnes Davonar yang juga merupakan penulis novel Ayah Mengapa Aku Berbeda. Pemilihan novel Surat Kecil Untuk Tuhan sebagai bahan kajian dilatarbelakangi oleh adanya keinginan untuk memahami kepribadian tokoh utama Keke, serta tokoh bawahan Ayah dan Andi yang ada dalam novel tersebut yang ditinjau dari sisi psikologi sastra, karena psikologi sastra merupakan salah satu pendekatan yang tepat digunakan untuk menganalisis kepribadian tokoh yang ada dalam novel.

Novel Surat Kecil Untuk Tuhan karya Agnes Davonar diangkat dari kisah nyata perjuangan gadis remaja penderita kangker ganas. Dalam menghadapi kanker ganas yang dideritanya, telah menumbuhkan gadis remaja tersebut menjadi pribadi yang baik hati, tangguh, dan pantang menyerah. Konflik-konflik psikologis yang timbul akibat dari penyakit yang dideritanya membuatnya menjadi pribadi yang unik dan menarik untuk diteliti.

Adapun penelitian ini difokuskan pada tokoh Keke yang merupakan tokoh utama serta tokoh Ayah dan Andi yang merupakan tokoh bawahan dalam novel Surat Kecil Untuk Tuhan karya Agnes Davonar. Endraswara (2008: 68) mengatakan bahwa fokus penelitian psikologi sastra adalah aspek kejiwaan dan pendekatan psikologis menekankan analisis terhadap keseluruhan karya sastra, baik segi intrinsik maupun ekstrinsik, namun yang ditekankan adalah segi intrinsiknya yang ditekankan pada penokohan atau perwatakannya.

Masalah yang diangkat dalam penelitian ini adalah: (1) struktur kepribadian tokoh utama Keke dalam novel Surat Kecil Untuk Tuhan karya Agnes Davonar ditinjau dari struktur kepribadian Sigmund Freud yang meliputi $i d$, ego, dan superego, (2) struktur kepribadian tokoh bawahan Ayah dalam novel Surat Kecil Untuk Tuhan karya Agnes Davonar ditinjau dari struktur kepribadian Sigmund Freud yang meliputi id, ego, dan superego, dan (3) struktur kepribadian tokoh bawahan Andi dalam novel Surat Kecil Untuk Tuhan karya Agnes Davonar ditinjau dari struktur kepribadian Sigmund Freud yang meliputi id, ego, dan superego.

Secara umum tujuan penelitian ini mendeskripsikan struktur kepribadian tokoh dalam novel Surat Kecil Untuk Tuhan karya Agnes Davonar dengan menggunakan pendekatan psikologi sastra (kajian dengan pendekatan psikologi kepribadian Sigmund Freud). Secara spesifik, penelitian ini mendeskripsikan: (1) struktur kepribadian tokoh utama Keke dalam novel Surat Kecil Untuk Tuhan karya Agnes Davonar ditinjau dari struktur kepribadian Sigmund Freud yang meliputi id, ego, dan 
superego, (2) mendeskripsikan struktur kepribadian tokoh tambahan Ayah dalam novel Surat Kecil Untuk Tuhan karya Agnes Davonar ditinjau dari struktur kepribadian Sigmund Freud yang meliputi id, ego, dan superego, serta (3) mendeskripsikan struktur kepribadian tokoh tambahan Andi dalam novel Surat Kecil Untuk Tuhan karya Agnes Davonar ditinjau dari struktur kepribadian Sigmund Freud yang meliputi id, ego, dan superego.

\section{METODE}

Sesuai dengan rumusan masalah dan tujuan penelitian, metode yang digunakan dalam penelitian ini adalah metode deskriptif kualitatif. Metode deskriptif dapat diartikan sebagai prosedur pemecahan masalah yang diselidiki dengan menggambarkan atau melukiskan keadaan subjek atau objek penelitian (novel, drama, cerita pendek, dan puisi) pada saat sekarang berdasarkan fakta-fakta yang tampak atau sebagaimana adanya (Siswantoro, 2010: 56), sedangkan menurut (Moleong, 2011: 4) metode kualitatif sebagai prosedur penelitian yang menghasilkan data deskriptif berupa kata-kata tertulis atau lisan dari orang-orang dan perilaku yang dapat diamati.

Data penelitian ini bersumber pada sebuah teks novel yang berjudul Surat Kecil Untuk Tuhan karya Agnes Davonar dan dalam bentuk verbal, yaitu berwujud kata, frasa atau kalimat (Siswantoro, 2010: 70). Data yang digunakan dalam penelitian ini berupa kata-kata dan tindakan yang berkaitan dengan struktur kepribadian tokoh Keke, Ayah, dan Andi berdasarkan tinjauan psikologi sastra (teori struktur kepribadian Sigmund Freud yang meliputi id atau das es, egoatau das ich, dan superego atau das ueber ich) dalam novel "Surat Kecil Untuk Tuhan" karya Agnes Davonar.

Sumber data dalam penelitian ini bersumber dari novel: Surat Kecil Untuk Tuhan, Nama Pengarang Agnes Davonar, penerbit Novelas, jumlah halaman 258, tahun terbit 2008.
Instrumen utama penelitian ini adalah peneliti itu sendiri untuk mempermudah dan menunjang kelancaran penelitian, peneliti menggunakan instrumen penelitian berupa kisikisi penjaringan data sesuai dengan struktur kepribadian tokoh Keke, Ayah, dan Andi dalam novel "Surat Kecil Untuk Tuhan" karya Agnes Davonar. Kisi-kisi ini juga berpengaruh teguh pada teori struktur kepribadian Sigmund Freud yang meliputi id atau das es, ego atau das ich, dan superego atau das ueber ich.

Teknik pengumpulan data dalam penelitian ini adalah Analisis Tekstual, analisis tekstual adalah kajian yang membahas isi dan makna perwatakan dalam kaitanya dengan struktur alur secara keseluruhan (Endraswara, 2008: 105).

Proses pengumpulan data penelitian ini dilakukan melalui tahapan (1) membaca keseluruhan teks novel "Surat Kecil Untuk Tuhan" karya Agnes Davonar secara berulangulang agar benar-benar memahami isi novel tersebut, (2) observasi terhadap isi dan cerita dari novel "Surat Kecil Untuk Tuhan" karya Agnes Davonar yang berkaitan dengan struktur kepribadian tokoh Keke, Ayah, dan Andi, (3) peneliti mengklasifikasi data sesuai dengan permasalahan, yaitu data yang berkaitan dengan struktur kepribadian tokoh Keke, ayah dan Andi ditinjau dari struktur kepribadian Sigmund Freud yang meliputi id atau das es, ego atau das ich, dan superego atau das ueber ich, (4) membaca dan memahami buku-buku referensi yang dianggap relevan.

Teknik analisis data dalam penelitian ini adalah menginterpretasikan data psikologis dalam teks novel. Interpretasi adalah proses membaca dan menjelaskan teks yang lebih sistematis dan lengkap (Endraswara, 2008: 74). Interpretasi sering juga disebut hermeunetika, artinya penafsiran secara mendalam terhadap karya sastra. Interpretasi memerlukan indikator dan data yang jelas, data yang dimaksudkan di sini adalah fakta-fakta psikologis dan faktafakta ini ditafsirkan secara psikologis, sehingga membentuk keutuhan makna. 
Hermeneutika memiliki banyak model dalam penafsiran sebuah teks, atau pesan. Salah satu model penafsiran dikemukakan oleh Ricoeur yang diperluas oleh Thomson. Dalam model tersebut ada empat tahap yang harus dilalui penafsir, yaitu (1) tahap pemahaman (comprehension), (2) tahap pengudaran (penguraian) karya (explication), (3) tahap penjelasan (explanation), dan (4) tahap penafsiran (interpretation

Teknik analisis data dalam penelitian ini meliputi (1) melakukan seleksi data sesuai dengan tujuan penelitian, (2) mengklasifikasi data struktur kepribadian tokoh Keke, Ayah, dan Andi dalam novel "Surat Kecil Untuk Tuhan" karya Agnes Davonar sesuai dengan teori struktur kepribadian Sigmund Freud yang meliputi $i d$ atau das es, ego atau das ich, dan superego atau das ueber ich, (3) setelah data diklasifikasi menurut golongannya, kemudian data ditafsirkan untuk dikembangkan sesuai dengan konsep teori, sehingga ditemukan struktur kepribadian tokoh Keke, Ayah, dan Andi dalam novel "Surat Kecil Untuk Tuhan" karya Agnes Davonar.

Untuk menilai apakah data-data yang diperoleh itu sudah sahih dan dapat dipercaya, maka peneliti perlu melakukan pemeriksaan secara seksama dan teliti, sebab, hanya data yang valid yang dapat diteliti. Kevalidan suatu data dilihat dari subtsansi, sumber data, maupun pengambilan datanya. Dalam penelitian ini menggunakan trianggulasi sumber, metode, dan teori. Trianggulasi adalah teknik pemeriksaan keabsahan data yang memanfaatkan sesuatu yang lain di luar data untuk keperluan pengecekan atau sebagai pembanding terhadap data itu (Moleong, 2011: 78).

Dalam penelitian ini menggunakan triannggulasi data dengan langkah-langkah (1) menyeleksi dan membandingkan beberapa diskusi forum yang membahas struktur kepribadian, (2) membandingkan data hasil pengamatan dengan pendapat dari ahli psikologi, (3) membandingkan keadaan perspektif pribadi dengan perspektif teman sejawat. Dengan demikian, validitas data yang ada dapat dipertanggungjawabkan, karena data akhir yang didapat adalah hasil perbandingan dari berbagai sumber data yang ada.

\section{HASIL DAN PEMBAHASAN HASIL PENELITIAN}

Berdasarkan tujuan penelitian, hasil penelitian menunjukkan adanya sejumlah temuan struktur kepribadian pada tokoh utama maupun tokoh bawahan yang meliputi (1) struktur kepribadian tokoh utama Keke dalam novel Surat Kecil Untuk Tuhan karya Agnes Davonar, (2) struktur kepribadian tokoh bawahan Ayah dalam novel Surat Kecil Untuk Tuhan karya Agnes Davonar, dan (3) struktur kepribadian tokoh bawahan Andi dalam novel Surat Kecil Untuk Tuhan karya Agnes Davonar. Hasil-hasil peneltian tersebut dipaparkan secara deskriptif.

Struktur Kepribadian Tokoh Utama Keke dalam Novel Surat Kecil Untuk Tuhan

\section{Id (Das Es)}

Kutipan berikut menunjukkan kepribadian unsur id pada utama tokoh Keke yang suka mengenang masa lalu.

Terkadang kalau melihat majalah model, aku masih bisa bayangkan ketika aku beberapa kali menjadi juara model di kejuaraan dan mungkin yang paling indah dalam hidupku adalah saat aku juga sempat membuat album cilik. (SKUT, 2008:3)

Membayangkan sesuatu merupakan bagian dari id yang digolongkan ke dalam proses primer. Dari kutipan cerita novel Surat Kecil Untuk Tuhan ini, menggambarkan betapa besarnya id yang ada dalam diri tokoh Keke. Id dalam diri Keke terlihat pada saat membayangkan ketika ia masih kecil, ia pernah beberapa kali menjadi juara model dan sempat membuat album cilik, tapi itu semua sudah berakhir akibat dari perceraian orang tuanya ia tidak bisa melanjutkan citacitanya. 


\section{Ego (Das Ich)}

Kutipan berikut menunjukkan kepribadian unsur ego (das ich) pada utama tokoh Keke.

Aku mencoba untuk tidur kembali, tapi tak kuasa menahan sinar matahari yang terus berbayang-bayang di wajahku. Baiklah, aku menyerah dan akan bangun. (SKUT, 2008:1)

Kutipan di atas menunjukkan bahwa dalam diri Keke terdapat ego yaitu mampu berpikir logis. Yang digambarkan bahwa Keke akhirnya memutuskan untuk bangun karena ia sadar bahwa hari sudah mulai siang dan seorang gadis tidak baik kalau bangun tidur terdahului oleh matahari, walaupun sebenarnya ia masih dalam keadaan mengantuk dan malas untuk bangun.

\section{Superego (Das Ueber Ich)}

Kutipan berikut menunjukkan kepribadian unsur supeego (das ueber ich) pada utama tokoh Keke.

Di dalam pikiranku selalu teringat nasehat ayah dan aku ingin membuat orangtuaku bangga. (SKUT, 2008:9)

Dalam kutipan cerita ini menunjukkan adanya unsur superego dalam jiwa Keke yaitu bersikap sopan, yang ditunjukkan bahwa Keke selalu mengingat nasehat Ayahnya dan ia ingin membuat bangga orang tuanya. Ia akan masuk ke sekolah yang berbasis agama agar ia bisa memperdalam ilmu agamanya serta menjadi anak yang berbudi pekerti yang baik.

\section{Struktur Kepribadian Tokoh Bawahan Ayah dalam Novel Surat Kecil Untuk Tuhan}

\section{Id (Das Es)}

Kutipan berikut menunjukkan kepribadian unsur id (das es) pada tokoh bawahan Ayah.
Aku sadar saat mengadukan hal tersebut kepada ayah, wajah ayah begitu bahagia. Hal itu terlihat dari raut mukanya, karena putri satu-satunya dalam keluarga mulai beranjak dewasa. (SKUT, 2008:19)

Dalam kutipan cerita menunjukkan adanya unsur $i d$ bekerja sesuai prinsip kenikmatan, yang digambarkan dari wajah Ayah yang terlihat begitu bahagia karena mengetahui bahwa putri satusatunya telah tumbuh menjadi seorang gadis dewasa, serta menjadi sosok gadis yang sangat cantik dan selalu ceria walau dalam keadaan apapun. Ayah tidak menyangka bahwa Keke sudah beranjak menjadi gadis remaja dan ia sudah mulai memberikan kepercayaan kepada Keke untuk menentukan segala pilihan dalam hidupnya.

\section{Ego (Das Ich)}

Kutipan berikut menunjukkan kepribadian unsur ego (das ich) pada tokoh bawahan Ayah.

Ayah mendengar perubahan sikapku dari bibi, dan ia memaklumi keputusanku. (SKUT, 2008:70)

Kutipan cerita ini menunjukkan bahwa ada unsur ego mampu berpikir logis, yang digambarkan saat ayah telah memaklumi perubahan sikap Keke yang tidak mau minum obat dan lebih suka mengurung diri di dalam kamar. Karena Ayah sadar bahwa Keke sedang dalam keadaan tertekan jiwanya dan Ayah mencoba untuk tidak menekan Keke agar ia tidak terlalu sedih menghadapi cobaan itu.

\section{Superego (Das Ueber Ich)}

Kutipan berikut menunjukkan kepribadian unsur supeego (das ueber ich) pada tokoh bawahan Ayah.

Ayah hanya bisa menangis dan Prof. Lukman berusaha membuat ayah tenang. Setelah keadaan mulai terkontrol dan ayah mulai tenang. (SKUT, 2008:45) 
Dalam kutipan cerita ini menunjukkan adanya unsur superego yaitu mampu mengendalikan diri, yang digambarkan saat Ayah mendengarkan penjelasan Prof bahwa Keke terserang penyakit kanker ia tak kuasa menahan tangisnya. Tapi ia sadar bahwa dengan menangis tidak akan menyelesaikan masalah maka ia mencoba untuk tetap tenang.

\section{Struktur Kepribadian Tokoh Bawahan Andi dalam Novel Surat Kecil Untuk Tuhan}

\section{Id (Das Es)}

Kutipan berikut menunjukkan kepribadian unsur id (das es) pada tokoh bawahan Andi.

"Ke... kenapa tiba-tiba begini..."

"Andi gak percaya.. Keke pasti cuma bercanda"

“Kee.." Teriak Andi. (SKUT, 2008:176)

Dalam kutipan cerita ini menunjukkan adanya unsur $i d$ dalam jiwa Andi yaitu bersifat kacau, yang digambarkan pada saat Keke ingin mengakhiri hubungannya dengan Andi, Andi pun menjadi sangat kacau dan tidak percaya kalau Keke mengakhiri hubungan dengannya. Andi tidak kuasa mendengarkan keputusan Keke dan mencoba untuk meyakinkan Keke lagi agar hubungan mereka tidak kandas dan berakhir, karena pikiran Andi sedang kacau, maka Andi berteriak-teriak agar Keke mau mendengarkan penjelasan darinya.

\section{Ego (Das Ich)}

Kutipan berikut menunjukkan kepribadian unsur ego (das ich) pada tokoh bawahan Andi.

Andi memang ingin mengantarkanku tapi sayang dia terbentur dengan kegiatan sekolah. (SKUT, 2008:102)

Dalam kutipan cerita ini menunjukkan adanya unsur ego dalam jiwa Andi yaitu menunda kepuasan, yang ditunjukkan pada saat Andi ingin mengantar Keke untuk melakukan proses radioterapi tapi karena terbenturnya kegiatan di sekolah maka Andi tidak bisa mengantar Keke dan menunda dorongan id tersebut.

\section{Superego (Das Ueber Ich)}

Kutipan berikut menunjukkan kepribadian unsur superego (das ich) pada tokoh bawahan Andi.

Ya, kalau Keke sakit jangan ikutlah.. Ntar tambah parah loh! Peringat Andi padaku. (SKUT, 2008:34)

Kutipan cerita ini menunjukkan adanya unsur superego dalam jiwa Andi yaitu bertindak sesuai norma, yang ditujukkan Andi pada saat memperingatkan Keke untuk tidak ikut pertandingan voli karena kondisi Keke yang sedang tidak enak badan. Andi tetap memberikan perhatiannya kepada Keke agar tidak terjadi sesuatu yang buruk karena Andi mengetahui bahwa kondisi Keke sedang tidak enak badan dan apabila dipakasakan untuk beraktivitas yang berlebihan akan membuat kodisi Keke semakin memburuk.

\section{PEMBAHASAN}

\section{Struktur Kepribadian Tokoh Utama Keke} Id (Das Es)

Struktur kepribadian id yang dimiliki oleh tokoh Keke dalam novel "Surat Kecil Untuk Tuhan" Karya Agnes Davonar tercermin ketika tokoh Keke dalam menjalankan semua aktivitasnya selalu dikendalikan oleh prinsip kenikmatan yang diwujudkan dengan proses primer, hal ini sesuai dengan pendapat (Alwisol, 2004: 15) bahwa proses primer merupakan reaksi membayangkan atau mengkhayal sesuatu yang dapat mengurangi serta menghilangkan tegangan yang dipakai untuk menangani stimulus kompleks. Tujuan dari tokoh Keke membayangkan adalah untuk mengurangi serta 
menghindari tegangan-tegangan yang ada dalam dirinya, sehingga ia memperoleh kenikmatan dengan cara membayangkan.

\section{Ego (Das Ich)}

Sesuai dengan pendapat (Alwisol, 2004: 15) struktur kepribadian ego yang dimiliki tokoh Keke dalam novel "Surat Kecil Untuk Tuhan" karya Agnes Davonar beroperasi mengikuti prinsip realita, yakni berpikir realistik menyusun rencana dan menguji apakah rencana itu menghasilkan objek yang dimaksud. Tokoh Keke dalam melaksanakan suatu tindakan selalu sesuai dengan rencana yang telah dipikirkan secara realistik dan mampu berpikir secara logis.

\section{Superego (Das Ueber Ich)}

Dalam novel "Surat Kecil Untuk Tuhan" karya Agnes Davonar, tokoh Keke dalam kehidupan sehari-hari selalu berpegang teguh dan patuh terhadap semua perintah dan larangan orang tuanya, yang sesuai dengan pendapat (Alwisol, 2004: 16) yaitu superego pada hakikatnya merupakan elemen yang mewakili nilai-nilai orang tua atau interpretasi orang tua mengenai standar sosial yang diajarkan kepada anak melalui berbagai larangan dan perintah. Apapun tingkah laku yang dilarang dianggap salah dan dihukum oleh orang tua, akan diterima anak menjadi suara hati (conscience) yang berisi apa saja yang tidak boleh dilakukan, apapun yang disetujui, dihadiahi, dan dipuji orang tua akan diterima menjadi standar kesempurnaan atau ego ideal yang berisi apa saja yang seharusnya dilakukan.

\section{Struktur Kepribadian Tokoh Bawahan Ayah}

\section{Id (Das Es)}

Dalam novel "Surat Kecil Untuk Tuhan” karya Agnes Davonar, tokoh Ayah dalam beraktivitas selalu dipengaruhi oleh prinsip kenikmatan yang diwujudkan dengan membayangkan atau mengkhayal, hal ini sesuai dengan pendapat (Alwisol, 2004: 15) bahwa proses primer merupakan reaksi membayangkan atau mengkhayal sesuatu yang dapat mengurangi serta menghilangkan tegangan yang dipakai untuk menangani stimulus kompleks.

\section{Ego (Das Ich)}

Dalam novel "Surat Kecil Untuk Tuhan" karya Agnes Davonar, struktur kepribadian ego yang ada dalam kepribadian tokoh Ayah mampu menunda kepuasan atau mampu mengendalikan dorongan-dorongan dalam menjalankan aktivitasnya yang sesuai dengan pendapat (Kartono, 1989: 129) yaitu ego menampilkan akal budi dan pikiran, selalu siap menyesuaikan diri, dan mampu mengendalikan dorongan-dorongan.

\section{Superego (Das Ueber Ich)}

Dalam novel "Surat Kecil Untuk Tuhan" karya Agnes Davonar, tokoh bawahan Ayah terlihat memiliki sikap mampu mengendalikan diri, mampu mengontrol atau serta berperilaku sesuai dengan norma-norma yang ada dalam lingkungan keluarga maupun masyarakat. Hal ini sejajar dengan pendapat (Kartono, 1989: 129) yaitu superego ini merupakan zat yang lebih tinggi pada diri manusia, yang memberikan garisgaris pengarahan etis dan norma-norma yang harus dianut dan fungsi terpenting dari superego ialah, sebagai hati nurani yang mengontrol dan mengeritik perbuatan sendiri.

\section{Struktur Kepribadian Tokoh Bawahan Andi}

\section{Id (Das Es)}

Sesuai dengan pendapat (Minderop, 2010: 21) yang mengatakan bahwa cara kerja id berhubungan dengan prinsip kesenangan, yaitu selalu mencari kenikmatan dan selalu menghindari ketidaknyamanan, sehingga menjadikan pribadi yang bersifat kacau. Seperti tokoh Andi dalam beraktivitas hanya ingin memperoleh kesenangan semata dan menghindari rasa sakit, sehingga 
mengakibatkan ia bersifat kacau dan tidak bisa berpikir secara rasional dalam melakukan aktivitas.

\section{Ego (Das Ich)}

Struktur kepribadian ego yang dimiliki tokoh Andi dalam novel "Surat Kecil Untuk Tuhan" karya Agnes Davonar terlihat pada saat Andi melaksanakan aktivitasnya yaitu mampu menunda kepuasan atau mampu mengendalikan dorongan-dorongan yang sesuai dengan pendapat (Kartono, 1989: 129) yaitu ego menampilkan akal budi dan pikiran, selalu siap menyesuaikan diri, dan mampu mengendalikan dorongandorongan. Dari paparan ini terlihat jelas bahwa sesungguhnya struktur kepribadian ego dari tokoh Keke diwujudkan dengan cara berpikir rasional dan selalu bekerja pada daerah kesadaran, serta bekerja untuk memuaskan $i d$.

\section{Superego (Das Ueber Ich)}

Dalam novel "Surat Kecil Untuk Tuhan" karya Agnes Davonar, tokoh Andi terlihat memiliki sikap mampu mengendalikan diri, mampu mengontrol atau serta berperilaku sesuai dengan norma-norma yang ada dalam lingkungan keluarga maupun masyarakat. Hal ini sesuai dengan pendapat (Kartono, 1989: 129) yaitu superego ini merupakan zat yang lebih tinggi pada diri manusia, yang memberikan garisgaris pengarahan etis dan norma-norma yang harus dianut dan fungsi terpenting dari superego ialah, sebagai hati nurani yang mengontrol dan mengeritik perbuatan sendiri.

\section{KESIMPULAN}

Berdasarkan hasil penelitian ini dapat disimpulkan bahwa (1) struktur kepribadian id tokoh utama Keke didominasi oleh proses primer (membayangkan dan menghayal), struktur kepribadian ego tokoh utama Keke timbul dan terjadi karena dorongan dari id (karena ego adalah ekskutif atau pelaksana), dan struktur kepribadian superego tokoh utama Keke didominasi oleh conscience, (2) struktur kepribadian id tokoh bawahan Ayah didominasi oleh tindak refleks dan proses primer, struktur kepribadian ego tokoh bawahan Ayah timbul dan terjadi karena dorongan dari id, struktur kepribadian superego tokoh bawahan Ayah didominasi oleh ego ideal, dan (3) struktur kepribadian id tokoh bawahan Andi didominasi oleh tindak refleks dan proses primer (membayangkan), struktur kepribadian ego tokoh bawahan Andi beroperasi mengikuti prinsip realita, struktur kepribadian superego tokoh bawahan Andi didominasi oleh conscience.

\section{DAFTAR PUSTAKA}

Alwisol. (2004). Psikologi Kepribadian. Malang: UMM Press.

Davonar, A. (2008). Surat Kecil Untuk Tuhan. Jakarta: Novelas.

Endraswara, S. (2008). Metode Penelitian Psikologi Sastra: Teori, Langkah, dan Penerapannya. Yogyakarta: FBS Universitas Negeri Yogyakarta.

Kartono, K. \& J. A. (1989). Hygiene Mental dan Kesehatan Mental dalam Islam. Bandung: CV. Mandar Madju.

Minderop, A. (2010). Psikologi Sastra. Jakarta: Yayasan Pustaka Obor Indonesia.

Moleong, L. (2011). Metodologi Penelitian Kualitatif. Bandung: PT Remaja Rosdakarya. Nurgiyantoro, B. (1995). Teori Pengkajian Fiksi. Yogyakarta: Gadjah Mada University Press.

Siswantoro. (2010). Metode Penelitian Sastra Analisis Struktural Puisi. Yogyakarta: Pustaka Pelajar. 